\title{
Arbuscular Mycorrhizal Symbiosis Limits Foliar Transcriptional Responses to Viral Infection and Favors Long-Term Virus Accumulation
}

\author{
Laura Miozzi, ${ }^{1}$ Marco Catoni, ${ }^{1}$ Valentina Fiorilli, ${ }^{2}$ Philip M. Mullineaux, ${ }^{3}$ Gian Paolo Accotto, ${ }^{1}$ and \\ Luisa Lanfranco ${ }^{2}$ \\ ${ }^{1}$ Istituto di Virologia Vegetale-CNR, Strada delle Cacce 73, 10135 Torino, Italy; ${ }^{2}$ Dipartimento di Biologia Vegetale, Università \\ degli Studi di Torino, Viale Mattioli 25, 10125 Torino, Italy; ${ }^{3}$ Department of Biological Sciences, University of Essex, Colchester \\ CO4 3SQ, United Kingdom
}

Submitted 18 May 2011. Accepted 12 August 2011.

Tomato (Solanum lycopersicum) can establish symbiotic interactions with arbuscular mycorrhizal (AM) fungi, and can be infected by several pathogenic viruses. Here, we investigated the impact of mycorrhization by the fungus Glomus mosseae on the Tomato spotted wilt virus (TSWV) infection of tomato plants by transcriptomic and hormones level analyses. In TSWV-infected mycorrhizal plants, the AM fungus root colonization limited virus-induced changes in gene expression in the aerial parts. The virus-responsive upregulated genes, no longer induced in infected mycorrhizal plants, were mainly involved in defense responses and hormone signaling, while the virus-responsive downregulated genes, no longer repressed in mycorrhizal plants, were involved in primary metabolism. The presence of the AM fungus limits, in a salicylic acid-independent manner, the accumulation of abscissic acid observed in response to viral infection. At the time of the molecular analysis, no differences in virus concentration or symptom severity were detected between mycorrhizal and nonmycorrhizal plants. However, in a longer period, increase in virus titer and delay in the appearance of recovery were observed in mycorrhizal plants, thus indicating that the plant's reaction to TSWV infection is attenuated by mycorrhization.

Arbuscular mycorrhiza (AM) is the term used to describe the mutualistic association between most land plants and fungi from the phylum Glomeromycota (Parniske 2008). The ability to form this association is widely distributed throughout the plant kingdom, and involves most agricultural, horticultural, and hardwood species (Bonfante and Genre 2010). The symbiosis develops in roots where the fungus colonizes the cortex and obtains carbon from the plant while facilitating the transfer of mineral nutrients to the root cells, through differentiated, highly branched intracellular fungal structures called arbuscules (Bonfante and Anca 2009). The benefits of the AM symbiosis on plant fitness are well described, including a better mineral nutrition and increased ability to overcome biotic and abiotic stresses (Aroca et al. 2008; Gernns et al. 2001;

Current address for M. Catoni: Department of Plant Biology, University of Geneva Science III, 30, quai Ernest-Ansermet 1211 Genève 4, Switzerland.

Corresponding author: L. Miozzi; E-mail: 1.miozzi@ivv.cnr.it

* The $\boldsymbol{e}$-Xtra logo stands for "electronic extra" and indicates that six supplementary tables and one supplementary figure are published online.
Hildebrandt et al. 2007; Pozo and Azcòn-Aguilar 2007; Pozo et al. 2010; van der Heijden and Sanders 2002).

The AM symbiosis can have important impacts on plant interactions with pathogens. Alleviation of damage caused by soilborne pathogens has been widely reported in mycorrhizal plants. Most studies deal with the reduction of incidence or severity of soilborne disease. mainly root rot or wilting caused by fungi such as Rhizoctonia, Fusarium, or Verticillium spp., and root rot caused by oomycetes, including Phytophthora, Pythium, and Alphanomyces spp. (Whipps 2004). A reduction in the deleterious effects by parasitic nematodes such as Pratylenchus and Meloidogyne spp. has also been reported (de la Peña et al. 2006; Li et al. 2006).

Different mechanisms may explain the protective role exerted by AM fungi; namely, improved plant nutrition, competition for colonization sites or photosynthesis, changes in the root apparatus or the microbial rhizosphere communities, and activation of plant defense mechanisms (Pozo and AzcònAguilar 2007; Wehnera et al. 2010; Whipps 2004). The requirement of a well-established AM symbiosis for induced resistance is generally accepted. Dealing with defense mechanisms, accumulation of reactive oxygen species (Blee and Anderson 2002), activation of phenylpropanoid and isoprenoid metabolism (Harrison and Dixon 1993; Strack and Fester 2006; Volpin et al. 1994, 1995), induction of specific isoforms of hydrolytic enzymes such as chitinases and glucanases (Dumas-Gaudot et al. 2000; Pozo et al. 2002), and alterations of hormone levels (Hause et al. 2007; Lopez-Raez et al. 2010) have been reported in mycorrhizal roots.

Experimental evidence also supports the hypothesis that AM symbiosis preconditions plant tissues for a more effective activation of defense responses against stress. This phenomenon, which is also induced in plants by necrotizing pathogens, plant-growth-promoting fungi and rhizobacteria, or treatment with various natural and synthetic compounds, is known as priming (Beckers and Conrath 2007; Conrath et al. 2006; Pozo and Azcòn-Aguilar 2007). Several results illustrate that primed responses are not restricted to areas colonized by the AM fungus but occur in the whole root system (Benhamou et al. 1994; Cordier et al. 1998; Li et al. 2006; Pozo et al. 2002; Yao et al. 2003).

Recently, more attention has been given to unraveling the functions of the root system in plant resistance and tolerance to aboveground attack, and evidence for the importance of roots as active modulators of shoot defense and resistance against herbivores and pathogens has been obtained (Erb et al. 
2009). However, the effects of the AM symbiosis in the protection against shoot pathogens remain to be elucidated and the few data available are contrasting (Pozo and Azcòn-Aguilar 2007; Pozo et al. 2010). Mycorrhization is known to reduce symptoms caused by a phytoplasma (Lingua et al. 2002), the necrotroph Alternaria solani (Fritz et al. 2006), and the bacterial pathogen Xanthomonas campestris (Liu et al. 2007) but the mechanisms on the basis of these responses are largely unknown. Shoots of mycorrhizal plants showed accumulation of insect anti-feedant compounds (Gange 2007). More recently, a microarray approach showed that the AM symbiosis induces the transcriptional regulation of many defense-related genes in shoots of Medicago truncatula. This was associated with an increased resistance to X. campestris (Liu et al. 2007). Alterations in phytohormone levels were also hypothesized to mediate shoot responses to biotic stress (Fiorilli et al. 2011; Pozo and Azcòn-Aguillar 2007). On the other hand, a higher susceptibility to fungal pathogens (Dugassa et al. 1996; Gernns et al. 2001; Lindermann 1994) and aphids (Gange and West 1994) has been reported. Very little is known concerning the interaction with virus infection. Mycorrhizal colonization was shown to increase the multiplication of some viruses (Daft and Okusanya 1973; Dehne 1982). Only one report described the disease symptoms: Shaul and associates (1999) demonstrated that leaves of Nicotiana tabacum mycorrhizal plant infected by Tobacco mosaic virus (TMV) showed an enhanced disease severity compared with the controls.
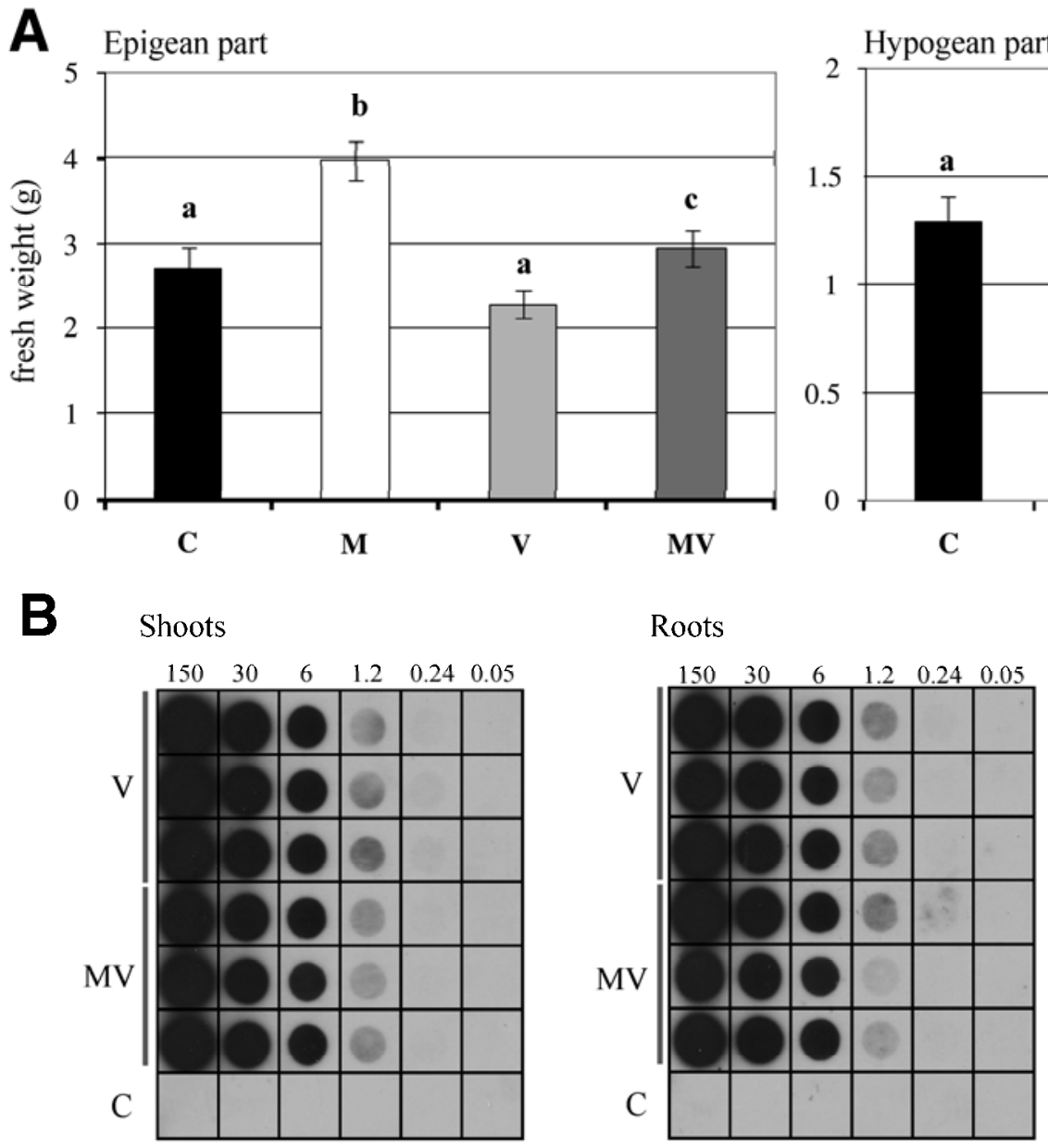

Fig. 1. A, Biomass of epigean (left) and hypogean (right) parts of mock-inoculated (C), mycorrhizal (M), Tomato spotted wilt virus (TSWV)-inoculated (V), and mycorrhizal TSWV-inoculated (MV) tomato plants, 14 days post-TSWV inoculation (= 42 days postinoculation with mycorrhizal inoculum). Bars represent standard errors. Different letters indicate significant differences (analysis of variance). B, Dot blot of total RNA extracted from shoots (left) and roots (right) of V, MV, and C plants 14 days postinoculum. Hybridization was performed with a TSWV-specific probe on the three pools of RNA (V and MV) used in the microarray experiment. A C plant was used as a negative control. Numbers above the panel indicate the amount (ng) of total RNA loaded in each square. 
the pathogen. Sample collection was performed 14 days after virus inoculation, when the first typical TSWV systemic symptoms, such as bronzing on leaves and distortion of the plant apex, appeared (Catoni et al. 2009). Apex and young expanding leaves (hereafter called "shoots") and radical terminal portions of roots (hereafter called "roots") were harvested.

At the time of sampling, viral symptoms on leaves were quite comparable between mycorrhizal and nonmycorrhizal plants. To better evaluate whether colonization by the AM fungus influences viral infection, the biomass of epigean and hypogean parts was measured (Fig. 1A). Mycorrhizal plants showed a growth increase compared with nonmycorrhizal ones (Fig. 1A, compare mycorrhizal $[\mathrm{M}]$ and mock-inoculated $[\mathrm{C}]$ plants). Viral infection dramatically suppresses the AMinduced growth increase (Fig. 1A, compare $\mathrm{M}$ and TSWVinfected mycorrhizal [MV] plants), especially in the roots. No differences in the amount of viral RNA in shoots and roots of MV and TSWV-infected (V) plants were evident in a semiquantitative analysis by dot blot (Fig. 1B).

\section{Comparative analysis of transcriptional responses of mycorrhizal and nonmycorrhizal plants to TSWV infection.}

The condition here considered (i.e., virus-infected mycorrhizal plants) involves the complex interaction of three organisms: plant, virus, and fungus. It is known that, even if microarray experiments are repeated with identical settings, considerable variation occurs between experiments; therefore, we set up a microarray experiment with an experimental design where each of the three biological conditions- $\mathrm{V}, \mathrm{M}$, or MV plantswere pairwise compared with $\mathrm{C}$ plants. The analysis was carried out on both shoots and roots. The results obtained by the analysis of the plant-TSWV and the plant-G. mosseae interactions were already validated and described by Catoni and associates (2009) and Fiorilli and associates (2009), respectively. In this work, we focused our attention on the tripartite virusfungus-plant interaction. The differential expression of a subset of genes regulated in MV plants, not yet validated in the previous works, was confirmed by quantitative real-time reverse-transcription polymerase chain reaction (qRT-PCR), using Ubiquitin (X58253) as reference gene (Table 1; Supplementary Table S1). The complete list of differentially expressed genes in at least one of the conditions considered can be found in Supplementary Table S2, and an overview of the GO categories represented in the differentially expressed (DE) genes can be found in Supplementary Figure S1.

The overall changes in gene expression detected in $\mathrm{V}, \mathrm{M}$, and MV plants are represented in the Venn diagram of Figure 2. The mycorrhizal fungus had a lower impact on the plant (655 genes in roots and 422 in shoots) than the virus $(1,166$ in roots and

Table 1. Validation of genes differentially expressed in response to Tomato spotted wilt virus infection in arbuscular mycorrhizal (MV) plants according to microarray data ${ }^{\mathrm{a}}$

\begin{tabular}{|c|c|c|c|c|c|c|}
\hline Sgn ID & Description & qRT-1 & qRT-2 & qRT-3 & Array & Validated \\
\hline \multicolumn{7}{|l|}{ Shoots } \\
\hline SGN-U230270 & Receptor-like protein kinase ark1 & 21.11 & 68.59 & 25.99 & 8.86 & Yes \\
\hline SGN-U231884 & Myb transcription factor myb117 & 10.80 & 27.22 & 8.98 & 7.94 & Yes \\
\hline SGN-U219598 & Putative similar to receptor protein kinase & 24.82 & 48.50 & 24.82 & 3.60 & Yes \\
\hline SGN-U215018 & Acid phosphatase & 0.14 & 0.02 & 0.01 & 0.16 & Yes \\
\hline \multicolumn{7}{|l|}{ Roots } \\
\hline SGN-U231884 & Myb transcription factor myb117 & 101.59 & 122.22 & 101.59 & 22.11 & Yes \\
\hline SGN-U222064 & Ap2 domain transcription factor-like & 132.51 & 337.79 & 922.88 & 28.24 & Yes \\
\hline SGN-U219598 & Putative similar to receptor protein kinase & 4.29 & 3.40 & 4.00 & 2.03 & Yes \\
\hline SGN-U217373 & Basic helix-loop-helixfamily protein & 0.29 & 0.16 & 0.29 & 0.15 & Yes \\
\hline SGN-U216203 & C-repeat binding factor & 43.21 & 125.08 & 86.42 & 9.06 & Yes \\
\hline SGN-U216297 & Ap2 domain transcription factor & 32.00 & 71.01 & 15.82 & 14.31 & Yes \\
\hline SGN-U216204 & C-repeat binding factor & 10.67 & 56.04 & 20.89 & 8.81 & Yes \\
\hline
\end{tabular}

${ }^{a}$ Quantitative reverse-transcription polymerase chain reaction was performed on the three biological replicates (qRT-1, qRT-2, and qRT-3) in shoots and roots. Expression values are indicated as fold changes of the differential expression in MV plants in respect to C plants. Ubiquitin was used as reference gene.
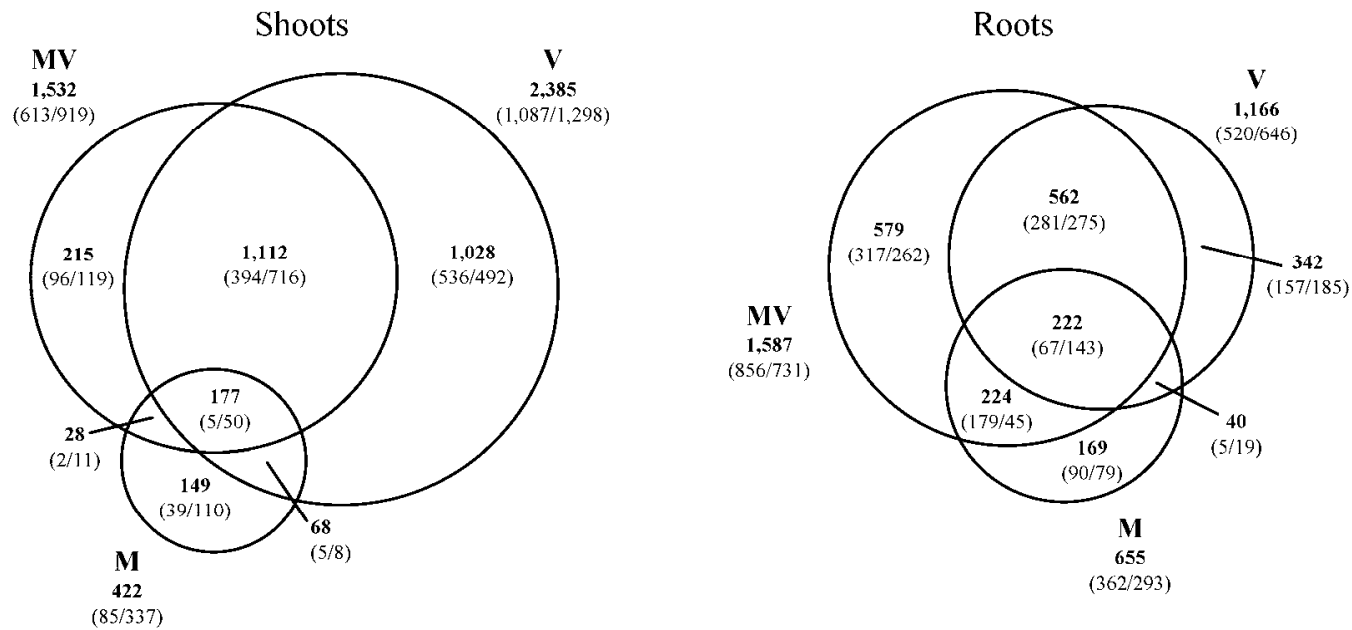

Fig. 2. Venn diagrams showing differentially expressed genes in response to Tomato spotted wilt virus (TSWV) infection in shoots (left) and roots (right) of arbuscular mycorrhizal (MV) plants, compared with those differentially expressed in TSWV-infected tomato shoots and roots (V) (Catoni et al. 2009) and in mock-inoculated mycorrhizal plants (M) (Fiorilli et al. 2009). Bold numbers indicate differentially expressed genes; numbers between blankets indicate upregulated (first number) and downregulated (second number) genes. The number of genes responsive in more than one condition is shown in the overlapping portion. The circle area is a proportional representation of the gene number. 
2,385 in shoots). In the roots of MV plants, where both microorganisms are presents, a higher number of genes $(1,587)$ were differentially expressed compared with the number of DE genes measured in the single interactions ( $\mathrm{V}$ and $\mathrm{M})$. In contrast, in MV shoots, where only the virus is physically present, the impact of both virus and fungus (1,532 DE genes) appeared intermediate between that observed for the virus (2,385 genes) and the mycorrhizal interaction (422 genes) separately.

A pool of 215 genes in shoots and 579 in roots were specifically regulated when both TSWV and $G$. mosseae were present. Several of these genes were related to carotenoid metabolism, defense, metabolism of sugars, transport, and response to hormones (with predominance of SA and ABA); however, no statistically significant GO category overrepresentation was observed.

The presence of the mycorrhizal fungus limited the gene response in the aerial part of MV plants, thus reducing the number of both up- and downregulated genes compared with the V plants (Fig. 2). To better investigate this effect, we focused our attention on the list of genes induced (580) or repressed (505) in shoots in response to viral infection of nonmycorrhizal plants but no longer regulated when the virus infected mycorrhizal plants (Supplementary Tables S3 and S4). The genes repressed in the shoots of $\mathrm{V}$ plants but no longer downregulated in MV plants were mainly involved in primary metabolism pathway. The analysis of overrepresented GO categories among genes upregulated in the shoots of $\mathrm{V}$ plants and no longer induced in MV plants highlighted a statistically significant enrichment of genes involved in defense mechanisms and response to hormones. In particular, a reduction in the expression of pathogenesis-related (PR) proteins, heatshock (HS) proteins, glutathione- $S$-transferases (GST), and WRKY transcription factors in the shoots of MV plants was observed compared with the V plants. For PR proteins, we observed both a reduction in the number of induced genes and a decrease in the fold-change levels in MV shoots compared with V shoots (Fig. 3; Supplementary Table S5).

\section{Hormone measurements.}

JA and SA have been identified as important players in induced defense of the plant against invading organisms (Dong 1998; Penninckx et al. 1998). Recently, these molecules were related to specific stages of root colonization by AM fungi (Blilou et al. 2000; Hause et al. 2007; Herrera-Medina et al. 2008; Isayenkov et al. 2005) and have been proposed to contribute to the balance between compatibility and defense in mutualistic as well as parasitic biotroph-root interactions (Gutjahr and Paszkowski 2009). Our transcriptomic analysis revealed that several genes upregulated in the shoots of $\mathrm{V}$ plants and no longer induced in MV plants were involved in the response to hormones. Therefore, we decided to measure the levels of SA and JA in our samples at the same time as the microarray analysis (i.e., 14 days postinoculation with TSWV inoculum). We found that TSWV induced a significant increase of SA in both shoots and roots, regardless of the presence of the AM fungus (Fig. 4). The physiological amount (in C plants) of SA detected in shoots was twice that measured in roots. After TSWV infection, the SA concentration increased dramatically (approximately 1,000 times) in the shoots and only moderately (approximately 3 times) in the roots. No effect of mycorrhizal colonization on SA levels was observed.

The physiological level of JA in shoots was under the detection limit of the method, and no increase was observed in any tested condition. In roots, a significant increase of the JA level in mycorrhizal plants was detected in both M and MV plants. No significant effect of the virus was observed (Fig. 4).
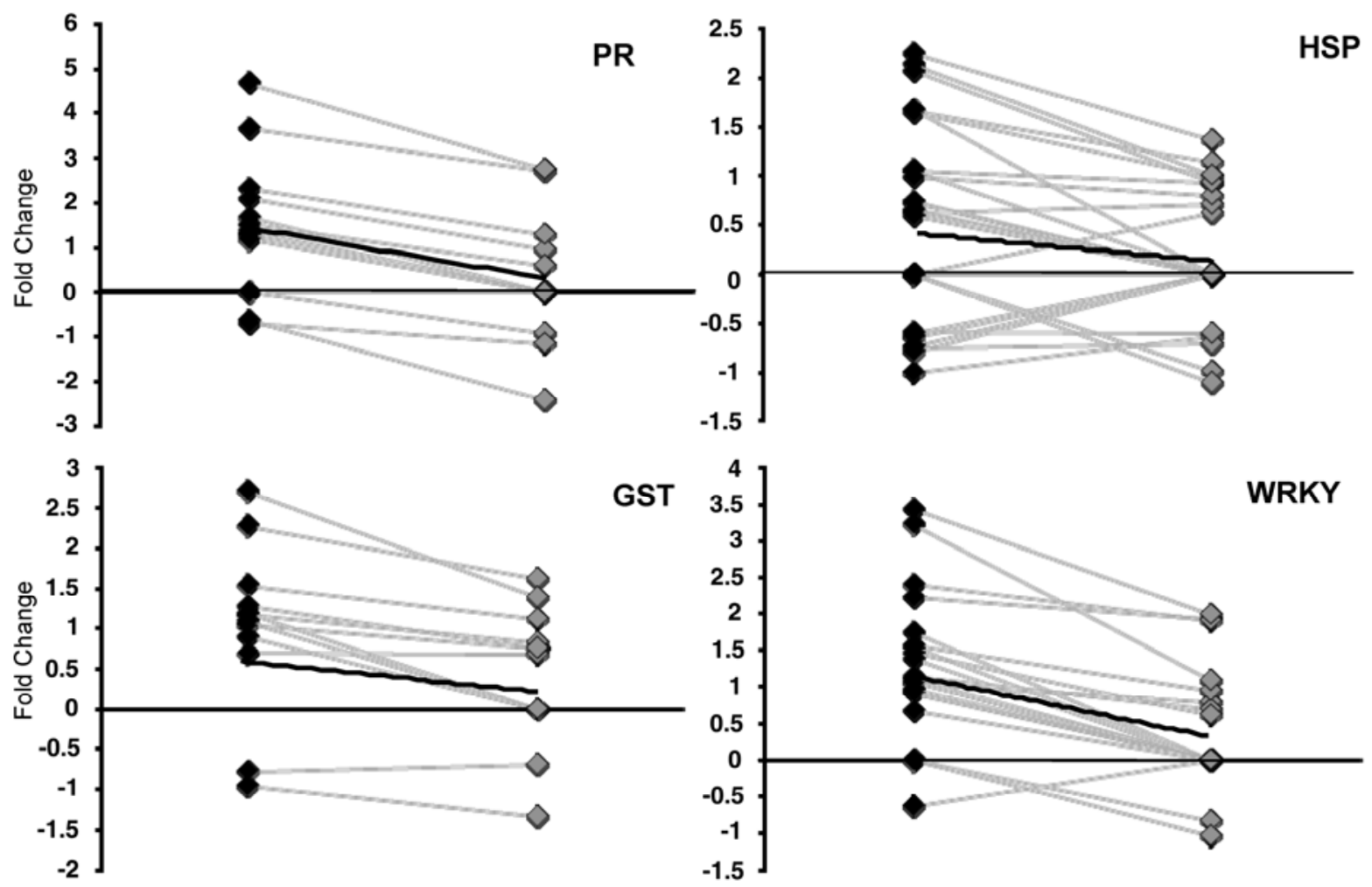

Fig. 3. Defense-related gene families showing significant decrease in the expression values between Tomato spotted wilt virus (TSWV)-inoculated (V) (black diamonds) and mycorrhizal TSWV-inoculated (MV) (gray diamonds) shoots; diamonds represent genes belonging to each gene family; gray lines join the expression value of the same gene in each condition; bold line represents the expression trend line. Significance was tested by $t$ test $(P$ value $<0.05)$. PR, pathogenesis-related proteins; HSP, heat-shock proteins; GST, glutathione-S-transferases; WRKY, WRKY transcription factors. 
In a previous work (Catoni et al. 2009), an involvement of ABA in the plant response to TSWV infection was suggested. Moreover, an antagonistic interaction between ABA and ethylene during AM formation was recently observed (MartínRodríguez et al. 2011). Thus, we measured the level of this hormone in mycorrhizal and nonmycorrhizal tomato plants infected by TSWV or mock-inoculated. The presence of TSWV induced a significant ABA accumulation in shoots of both $\mathrm{V}$ and MV plants. However, in the MV plants, the level of ABA was significantly lower than in $\mathrm{V}$ plants (Fig. 4). In tomato roots, the quantity of ABA did not show any significant difference in any of the tested conditions (data not shown).

\section{Long-term analysis.}

Microarray analysis gave us a picture of the transcriptomic changes occurring in the plants in response to virus infection or mycorrhizal colonization at the selected time point (i.e., 14 days post-virus inoculation, when the first TSWV symptoms became evident). At this time, a significant reduction in the response of genes involved in defense mechanisms and response to hormones was observed in the shoots of MV plants compared with the shoots of $\mathrm{V}$ plants (discussed above). This prompted us to investigate how the tripartite interaction evolves over time, compared with the bipartite ones, in order to highlight whether the reduced gene response can have an effect on the viral infection in a longer period of time. A set of plants representing all four conditions $(\mathrm{C}, \mathrm{V}, \mathrm{M}$, and $\mathrm{MV}$ ) was maintained in the same growth conditions for a period of up to 56 days postinoculation (dpi) with TSWV. Changes in mycorrhization level, viral symptom development (recovery), and virus concentration were analyzed.

AM fungal colonization was evaluated in M and MV plants at the end of the experiment, measuring several parameters; only the percentage of arbuscules within infected areas was statistically higher (Fig. 5A).

Virus-infected plants can occasionally be subjected to a phenomenon called "recovery", characterized by disappearance or reduction of symptoms in plants initially showing severe disease and by immunity to reinoculation with the same virus (Pennazio 2010). In order to estimate whether the presence of the fungus can interfere with development of the viral infection, we measured the frequency of spontaneous recovery in $\mathrm{MV}$ and $\mathrm{V}$ plants. At 34 days post-TSWV inoculation, $65 \%$ of $\mathrm{V}$ plants and $25 \%$ of MV plants showed recovery. The difference between these two sets of plants decreased at 44 dpi and disappeared at 56 dpi (Fig. 5B).

When the amount of viral RNA was measured by qRT-PCR, the results indicated no differences at $14 \mathrm{dpi}$; however, a significant increase of viral concentration was measured in MV plants compared with $\mathrm{V}$ plants at 34 and 56 dpi (Fig. 5C).
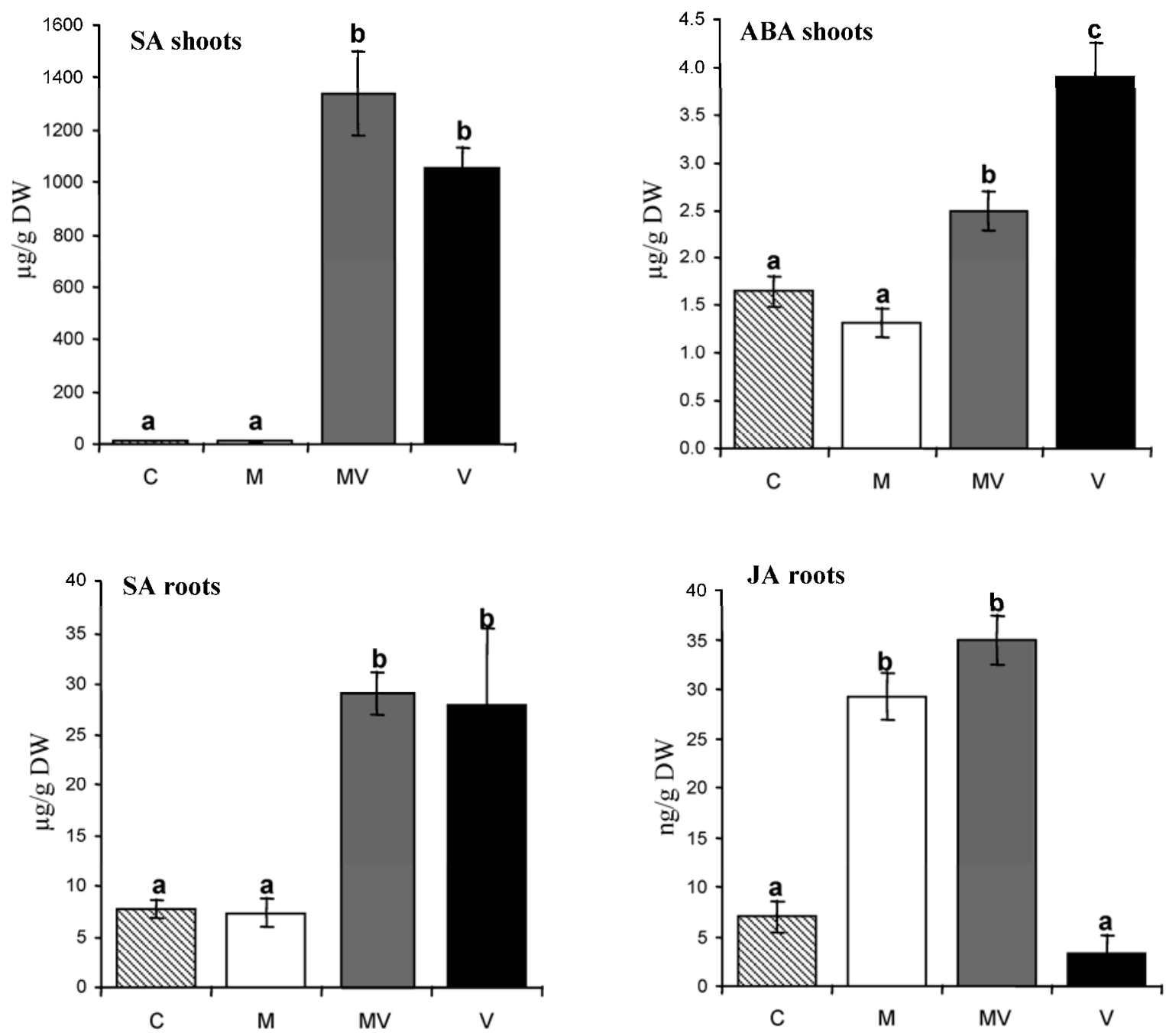

Fig. 4. Hormone levels in tomato shoots and roots of mock-inoculated (C), mycorrhizal (M), Tomato spotted wilt virus (TSWV) infected (V), and TSWVinfected mycorrhizal (MV) plants. Values are the average of 14 (shoots) and 7 (roots) samples. Bars represent standard errors. Different letters indicate significant differences (analysis of variance). SA, salicylic acid; JA, jasmonic acid; ABA, abscisic acid; DW, dry weight. 


\section{DISCUSSION}

\section{Effect of mycorrhiza on viral infection.}

In natural ecosystems, plants simultaneously interact with a broad panel of microorganisms, both pathogens and symbionts, giving rise to a complex system where the final outcome is not just the sum of the specific response to each microbe. Here, we investigated how tomato plants transcriptionally respond to the concurrent presence of two microorganisms with a different lifestyle and naturally occurring in the environment: the pathogenic virus TSWV and the mycorrhizal fungus $G$. mosseae. TSWV invades all parts of the plant, mainly developing symptoms in the aerial part, and the symbiotic fungus colonizes the roots; therefore, for the analysis, we considered both the aerial (shoots) and the underground (roots) parts of the plant.

Compared with the corresponding bipartite interactions (TSWV-infected plants and mycorrhizal plants), shoots and roots of mycorrhizal plants appeared to differently respond to TSWV infection: we observed an "additive" effect (higher number of regulated genes compared with the single interactions) of the transcriptional responses in roots, likely due to the physical co-presence of the two organisms, while, in the aerial part of plants, the presence of the mycorrhizal fungus limited gene response due to viral infection, strongly reducing the number of both up- and downregulated genes. The number of genes perturbed by the TSWV infection in the shoots of mycorrhizal plants is lower than that perturbed by the virus in nonmycorrhizal plants (Fig. 2). In particular, fewer genes involved in defense response and hormone response are upregulated and fewer genes involved in primary metabolism are downregulated. Activation of defense-related genes is a common process in several plantvirus interactions (Catoni et al. 2009; Dardick 2007; Senthil et al. 2005). On the other hand, it was shown that, in shoots of tomato plants colonized by the G. mosseae, several genes involved in defense mechanisms are downregulated (Fiorilli et al. 2009). In the shoots of TSWV-infected mycorrhizal plants, we observed an intermediate situation. Several classes of genes involved in defense (i.e., those coding for PR proteins, WRKY transcription factors, HS-related proteins, chitinases, and GST activated in response to virus) (Catoni et al. 2009) were less (decreasing fold change) or not activated in virus-infected mycorrhizal plants (Fig. 3). This is in agreement with a lower accumulation and a delay in activation of PR1 and PR3 proteins observed in mycorrhizal tobacco (Shaul et al. 1999) and associated with enhanced virus infectivity.

A reduction in the number of downregulated genes involved in primary metabolism was also observed in TSWV-infected mycorrhizal plants compared with the TSWV-infected nonmycorrhizal ones. Repression of primary metabolism was observed previously in several plant-virus interactions and is commonly linked to the development of symptoms (Catoni et al 2009; Dardick 2007; Senthil et al. 2005). In particular, effects on carbohydrate allocation have been associated with virus infections (Clark and Adams 1977; Maule at al. 2002) and some studies have shown that active infection sites can function as photosynthetic sinks (Herbers et al. 2000; Shalitin and Wolf 2000; Tecsi et al. 1996), in order to expand availability of resources for virus replication and movement.

In spite of such a differential transcriptional response, no changes in virus accumulation or symptom severity was observed between $\mathrm{V}$ and MV plants, at the time of the microarray analysis (14 day post-virus inoculation). However, by extending the time elapsed since virus inoculation, we did observe a continuous increase in virus concentration in infected mycorrhizal plants compared with infected nonmycorrhizal individuals, with a maximum at $56 \mathrm{dpi}$. Therefore, we speculated that mycorrhizal plants could become somehow more sensitive to viral presence over time.

Our data are in agreement with previous studies, indicating an increase in symptom development and virus accumulation in leaves of virus-infected mycorrhizal plants (Daft and Okusanya 1973; Shaul et al. 1999). AM fungi are known to increase the uptake of nutrients, especially phosphorous and nitrogen into their host plants (Guether et al. 2009; Javot et al. 2007). Increasing phosphorous content has been associated with an increase in virus infection (Borer et al 2010; Daft and Okusanya 1973). However, by artificially raising the level of phosphorus, Shaul and colleagues (Shaul et al. 1999) failed to reproduce the increased susceptibility observed in TMV-infected mycorrhizal tobacco plants. Even in cases where the AM symbiosis improved tolerance to the pathogen, the differential response of mycorrhizal plants was not related to enhanced phosphate nutrition (Wehnera et al. 2010).

It is also interesting to note that the recovery phenotype is delayed in MV plants. Recovery is an unstable condition of virus-infected plants that appears and disappears over time. Our observations were limited to $56 \mathrm{dpi}$, when both types of plants showed the same number of individuals with recovery; however, long-term experiments could again highlight changes between mycorrhizal and nonmycorrhizal plants.

At the end of the experiment (56 dpi), the only difference in AM fungal colonization between $\mathrm{M}$ and MV plants was the increased percentage of arbuscules within infected areas (Fig. 5A). This increase indicates that the fungal arbuscules are more concentrated in MV roots compared with M roots and
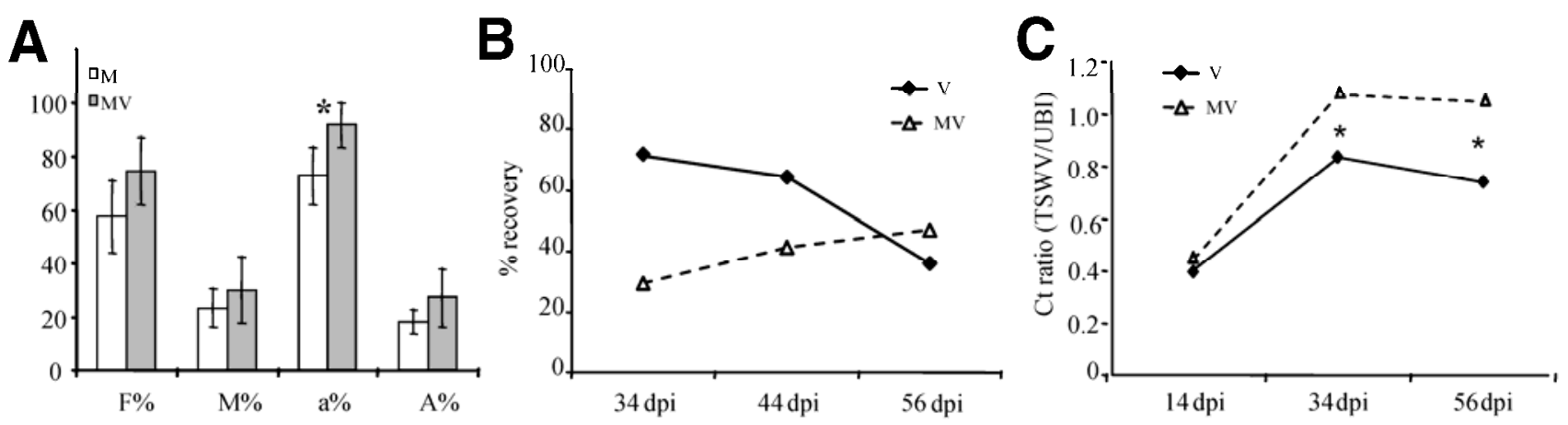

Fig. 5. A, Mycorrhization levels of mycorrhizal (M) and Tomato spotted wilt virus (TSWV)-infected mycorrhizal (MV) plants were assessed according to the method described by Trouvelot and associates (1986). F\%, frequency of mycorrhization; M\%, intensity of mycorrhization; a\%, percentage of arbuscules within infected areas; A\%, percentage of arbuscules in the root system. Asterisk (*) indicates statistically significant differences (Kruskal-Wallis). B, Percentage of plants showing recovery; plants with not clear or not stable recovery were not considered. C, Virus concentration in shoots (young leaf), measured by quantitative real-time reverse-transcription polymerase chain reaction. Asterisk (*) indicates statistically significant differences. 
could suggest that the fungus is slightly more active in MV plants. However, it is worth noting that the other parameters of fungal colonization didn't show any statistical differences and that, based on microarray data, the mycorrhiza-inducible phosphate transporter (PT3) which can be considered a marker of a functional AM symbiosis was similarly active in both $\mathrm{M}$ and MV roots (fold change [FC] = 12 in both $\mathrm{M}$ and MV). Therefore, we couldn't currently highlight a clear effect of the virus on the mycorrhiza.

\section{Hormone signaling in mycorrhizal-infected plants.}

Hormones are active molecules regulating several biological processes, including responses to abiotic and biotic stresses. SA and JA are well known to play an important role in regulating the defense responses against pathogens (Alvarez 2000; Kovač et al. 2009; Singh et al. 2004) and a fast-growing number of studies are demonstrating that $\mathrm{ABA}$ is also implicated in the stress-response signaling network (Asselbergh et al. 2008b). Moreover, JA and, more recently, ABA have been shown to be prominent in the establishment and maintenance of the mycorrhizal symbiosis (Gutjahr and Paszkowski 2009; Hause et al. 2002, 2007; Herrera-Medina et al 2007; Isayenkov et al. 2005).

An enrichment in genes responsive to SA and ABA but not to JA was observed in the TSWV-infected mycorrhizal plants and the levels of SA, ABA, and JA were affected differently by the virus and the fungus.

\section{SA and JA.}

SA is well known to increase in response to infection by viruses and other biotrophic pathogens (Chaturvedi and Shah 2007; Singh et al 2004). SA levels were enhanced in TSWVinfected plants, with an increase significantly higher in shoots than in roots (Fig. 4). The same hormone was not affected by the presence of the AM fungus, in agreement with observations that the role of SA in mycorrhiza formation is local and limited to the site of interaction (Hause et al 2007; Pozo and Azcòn-Aguilar 2007). In support of these observations, the nonexpressor of PR gene 1 (NPRl; SGN-U229275), an important regulatory component of SA signaling involved in the activation of PR genes (Dong 2004), was induced in the shoots of both $\mathrm{V}(\mathrm{FC}=1.9)$ and $\mathrm{MV}(\mathrm{FC}=1.5)$ plants but not in $\mathrm{M}$ plants. A consequent induction of PR proteins was observed mainly in the $\mathrm{V}$ shoots and, with lower intensity, in the MV shoots (Fig. 3).

JA is usually associated with defense against necrotrophic pathogens and does not have a systemic role in defense against viruses although, recently, it was observed to have a limited effect in early local defenses (Kovač et al. 2009). It is widely accepted that JA is involved in the process of mycorrhiza formation in roots, as demonstrated in several host-fungus interactions (Hause et al. 2007) as well as specifically in tomato (Herrera-Medina et al. 2008). In our conditions, increased levels of JA in mycorrhizal roots were detected regardless of the presence of TSWV infection.

To date, several reports have provided evidence of improved resistance in mycorrhizal plants against a broad panel of pathogens, leading to a proposed mycorrhiza-induced resistance (MIR). The partial suppression of the SA-dependent response in the plant, compensated by an enhancement of the JA-regulated response, is one hypothesis for the "priming" of the JAdependent defense mechanism in MIR (Pozo and Azcón-Aguilar 2007). During TSWV infection, no significant change was observed in SA accumulation in mycorrhizal and nonmycorrhizal plants. Similar levels of SA were coupled with similar levels of virus accumulation and symptom development (at 14 dpi), indicating that mycorrhization was unable to counteract
TSWV infection. Moreover, the significantly lower upregulation of PR proteins occurring in MV plants compared with V plants, together with the temporary decrease in recovery and the increase in virus accumulation in the late steps of infection, suggests a more complex cross-talk among phytohormones, not limited to SA and JA only.

ABA.

Recently, it became evident that, in addition to SA and JA, ABA can play important roles in defense responses (Bari and Jones 2008). In both V and MV plants, we measured an increase of ABA in response to TSWV infection. However, in MV plants, the level of ABA was significantly lower than that measured in $\mathrm{V}$ plants. It is interesting to note that this reduction was SA independent; even if ABA and SA pathways are often antagonistic, no changes in SA levels were actually measured in V and MV plants. We already observed (Catoni et al. 2009) that, in the roots of $\mathrm{V}$ plants, the gene coding for the 9-cis-epoxycarotenoid dioxygenase (SGN-U214605), a key enzyme in the ABA biosynthesis, was upregulated $(\mathrm{FC}=3.1)$ and the gene coding for the ABA 8'-hydroxylase CYP707A1 (SGNU222532), the key enzyme for the ABA degradation, was downregulated $(\mathrm{FC}=0.3)$. No differential expression of these genes was observed in the shoots, where we measured an increase in ABA level. A similar situation can be observed in MV plants, where the same genes were still upregulated $(\mathrm{FC}=$ 4.8) and downregulated $(\mathrm{FC}=0.3)$ only in the roots while the ABA increase was measured in the shoots. On the other hand, in the aerial part of both $\mathrm{V}$ and MV plants, we observed the induction of ABA-responsive element-binding factors that mediate ABA-regulated gene expression: two (SGN-U224515 and SGN-U224383) were both upregulated in MV shoots $(\mathrm{FC}=$ 2.2 and $\mathrm{FC}=1.6$, respectively) and one (SGN-U224383) was upregulated in $\mathrm{V}$ shoots $(\mathrm{FC}=1.6)$. It is known that ABA can move from roots to shoots (Wilkinson and Davies 2010), and we suppose that modifications in ABA synthesis in roots can affect the level of this hormone in shoots.

The precise role of ABA in plant-pathogen interactions is still unclear. In tomato, high ABA levels are predominantly associated with high susceptibility but, in Arabidopsis, both positive and negative effects have been reported (Asselbergh et al. 2008a). It is known that TMV infection is able to increase ABA concentration in tobacco (Fraser 1982; Whenham et al. 1986) and that infecting bacteria enhance ABA levels in early stages of interaction in order to promote plant infection (Maksimov 2009). Mutants unable to synthesize ABA show enhanced resistance to several biotrophic and necrotrophic fungi (Maksimov 2009; Mauch-Mani and Mauch 2005). The positive effect of ABA against virus infection is mainly related to its ability to enhance callose deposition by activating callose synthases and suppressing $\beta$-1,3-glucanases (Flors et al. 2008; Ton and MauchMani 2004). Callose accumulation at plasmodesmata is considered a defense mechanism against viruses, producing a physical barrier restricting virus movement in both compatible and incompatible interactions, while its degradation promotes pathogen spread (Zavaliev et al. 2010). $\beta-1,3-$ Glucanases are PR proteins able to degrade callose (van Loon and van Strien 1999). Plants deficient in basic $\beta$-1,3-glucanases are more resistant to viral infection (Beffa et al. 1996). Increased expression of $\beta-1,3-$ glucanases in virus-infected cells can promote the spread of the virus by enhancing degradation of callose, leading to an increase of the plasmodesmatal size exclusion limit and, consequently, increasing local lesion size (Bucher et al. 2001). We found two $\beta$-1,3-glucanases (SGN-U215958 and SGN-U214527) upregulated in both $\mathrm{V}(\mathrm{FC}=8.8$ and 4.2 , respectively $)$ and MV shoots ( $\mathrm{FC}=4.3$ and 3.1, respectively) and two other $\beta$-1,3-glucanase isoforms (SGN-U218121 and SGN-U220005) downregulated in 
V shoots (Catoni et al 2009) but no longer regulated in MV shoots. This expression pattern correlates well with the ABA level, lower in MV than in V plants (Fig. 4).

\section{Conclusion.}

The aim of this work was to investigate how the colonization by an AM fungus can influence plants' response to virus infection, providing new knowledge of the complexity of this naturally occurring tripartite virus-fungus-plant interaction. Our data showed that mycorrhization causes a dramatic modification in the levels of plant transcripts, particularly in shoots, where, out of the total number of DE genes, more than 1,000 were regulated in $\mathrm{V}$ plants but not in MV plants. This indicates that the root colonization has a strong systemic effect, also highlighted by the fact that ABA level in MV shoots was intermediate between that measured in $\mathrm{M}$ and $\mathrm{V}$ shoots. Curiously, these changes were not paralleled by differences in virus symptoms or concentration, at least at the time of the transcriptomic analysis. Differences in plant phenotype could be detected later on, in both the development and evolution of recovery and virus concentration. In mycorrhizal plants, the recovery phenotype was delayed and the concentration of TSWV became higher. These results highlighted the complexity of the dialogue between the host plants and the microbes, indicating that the protective effect induced by mycorrhizal fungi is not a general phenomenon but is the result of a delicate equilibrium depending on these organisms' different life styles.

\section{MATERIALS AND METHODS}

\section{Biological materials.}

Solanum lycopersicum L. ('Moneymaker') seed were surface sterilized by washing in $70 \%$ ethanol with a few drops of Tween 20 for $3 \mathrm{~min}$ and in sodium hypochlorite $5 \%$ for $13 \mathrm{~min}$, and rinsed three times in distilled water for $10 \mathrm{~min}$. Seed were placed in agar $/ \mathrm{H}_{2} \mathrm{O}(0.6 \%)$ in petri dishes, incubated for 5 days in the dark $\left(25^{\circ} \mathrm{C}\right)$, and then exposed to light for 4 days. The seedlings were transferred to pots with sterile quartz sand. Inoculation of G. mosseae (T. H. Nicolson \& Gerd.) Gerd. \& Trappe BEG12 (Biorize) was performed by mixing the inoculum with sterile quartz sand $(30 \%$ [vol/vol] $)$. The plants were grown in a growth chamber under a regime of $14 \mathrm{~h}$ of light $\left(24^{\circ} \mathrm{C}\right)$ and $10 \mathrm{~h}$ of darkness $\left(20^{\circ} \mathrm{C}\right)$ and watered at a rate of 125 $\mathrm{ml}$ per plant twice a week with water and once a week with a modified Long Ashton solution containing a low phosphorus concentration $\left(3.2 \mu \mathrm{M} \mathrm{Na} \mathrm{HPO}_{4} \cdot 12 \mathrm{H}_{2} \mathrm{O}\right)$ (Hewitt 1966). For recovery analysis, form 14 to $56 \mathrm{dpi}$, plants were watered with a modified Long Ashton solution containing a higher phosphorus concentration $\left(32 \mu \mathrm{M} \mathrm{Na} \mathrm{HPO}_{4} \cdot 12 \mathrm{H}_{2} \mathrm{O}\right)$ (Hewitt 1966) compared with that used before. Plants were inoculated with TSWV (genus Tospovirus) isolate T1012 (Istituto di Virologia Vegetale collection) 28 days after planting (at the four-leaf stage). The inoculum was prepared from systemically infected leaves of TSWV-infected tomato plants. Approximately $1 \mathrm{~g}$ of infected leaf tissue was homogenized in $10 \mathrm{ml}$ of inoculation buffer $(10$ $\mathrm{mM}$ sodium diethyldithiocarbamate, $5 \mathrm{mM}$ ethylene diamine tetracetic acid, and $20 \mathrm{mM}$ sodium sulfite). The inoculum was applied to the upper side of leaves by gentle rubbing with Carborundum. Mock-inoculated plants, used as control, were subjected to the same protocol using uninfected leaf tissue.

Plants were harvested $14 \mathrm{dpi}$; in order to check virus infection, a freshly cut petiole of the youngest available leaf of every plant was printed on a positively charged nylon membrane (Roche, Mannheim, Germany). Membranes were then hybridized with a digoxigenin-labeled TSWV-specific probe (Vaira et al. 1995). Only infected plants were retained for further analysis. Root and shoot fresh biomass of control, virus- infected, mycorrhizal, and virus-infected mycorrhizal plants were measured and evaluated with the analysis of variance. Samples were then immediately frozen in liquid nitrogen and stored at $-80^{\circ} \mathrm{C}$. Mycorrhization level was assessed according to the method of Trouvelot and associates (1986). Only roots showing high percentages for the four parameters considered (frequency of mycorrhiza formation $>50 \%$, intensity of mycorrhiza formation $>10 \%$, percentage of arbuscules within infected areas $>60 \%$ and percentage of arbuscules in the root system $>10 \%$ ) were used for RNA extraction.

\section{Dot-blot analysis.}

Semiquantitative analysis of virus concentration was performed using dot-blot hybridization. A mock-inoculated sample was used as control. A starting quantity of $150 \mathrm{ng}$ of total RNA and fivefold serial dilution was blotted onto a positively charged nylon membrane (Roche) using the Minifold system (Schleicher \& Schuell, Dassel, Germany). Membranes were then hybridized with a TSWV-specific probe as described above.

\section{RNA extraction and microarray experiment.}

Total RNA was isolated with Trizol reagent (Invitrogen, Carlsbad, CA, U.S.A) following the manufacturer's instructions. RNA quantification was performed using a Nanodrop 1000 Spectrophotometer, and RNA integrity was examined with Bioanalyzer 2100 (Agilent Technology, Santa Clara, CA, U.S.A.). RNAs were pooled in four biological replicates for each condition, each pool containing three to four plants; for mycorrhizal roots, the samples were grouped considering comparable frequency of mycorrhization and intensity of mycorrhization values in each. The same pools were prepared for shoot and root samples.

The TOM2 microarrays were obtained from the Center for Gene Expression Profiles (Cornell University, Ithaca, NY, U.S.A.). Each microarray contains 11,769 oligonucleotide probes designed based on gene transcript sequences from the Lycopersicum Combined Built number 3 unigene database. Three biological replicates were analyzed and a "dye swap" approach was adopted. Total RNA (500 ng) was used to generate direct fluorescently labeled cRNA using the Low RNA input linear amp kit (Agilent Technology) according to the manufacturer's instructions.

Array slides were prehybridized, hybridized, washed, and scanned as described by Fiorilli and associates (2009). Fluorescence data were processed using ImaGene software (version 5.6; BioDiscovery Inc., El Segundo, CA, U.S.A.) using default quality controls and segmentation values with appropriate adjustment according to the signal intensity of each slide. Normalization and analysis of microarray data were performed using the Limma package (Smyth et al. 2005). Within- and between-array normalization was performed (Lowess normalization). A gene was considered differentially expressed when i) its false discovery rate was $<0.05$ and ii) its $\mathrm{FC}$ was $\leq 0.67$ or $\geq 1.5\left(\log _{2}\right.$ ratio $\leq-0.58$ or $\left.\geq 0.58\right)$.

\section{Functional and metabolic analysis.}

GO annotation was obtained using Blast2go software (Conesa et al. 2005), with default parameters. The lists of up- or downregulated genes were searched for overrepresented GO terms. $P$ values were computed with Fisher's exact test and a $P$ value $<$ $10^{-3}$ was considered statistically significant (Bluthgen et al. 2005). The analysis was performed using a set of Perl and C programs available from the authors upon request.

\section{Real-time qRT-PCR analysis.}

The RNA samples used for the hybridization experiments were treated with Turbo DNase free (Ambion, Foster City, CA, 
U.S.A.) according to the manufacturer's instructions. DNA contaminations were evaluated by RT-PCR using $18 \mathrm{~S}$ rRNAspecific primers of tomato and One Step RT-PCR kit (Qiagen). Single-strand cDNA was obtained from approximately 1,500 ng of total RNA using Oligo-dT (Invitrogen) primers and StrataScript reverse transcriptase (Stratagene, La Jolla, CA, U.S.A.). The volume of RNA samples was brought to $40 \mu \mathrm{l}$ and then $10 \mu \mathrm{l}$ of Mix (composed of $0.6 \mu \mathrm{l}$ of Oligo-dT at 500 $\mathrm{ng} / \mu \mathrm{l}$ and $9.4 \mu \mathrm{l}$ of distilled water) was added. The samples were incubated for $5 \mathrm{~min}$ at $65^{\circ} \mathrm{C}$ and $10 \mathrm{~min}$ at room temperature. A master mix $(8.5 \mu \mathrm{l})$ containing $5 \mu \mathrm{l}$ of StrataScript RT buffer, $1 \mu$ l of RNase inhibitor $\left(40 \mathrm{U}^{-1} \mathrm{l}^{-1}\right), 2 \mu \mathrm{l}$ of dNTPs (10 $\mathrm{mM}$ ), and $0.5 \mu \mathrm{l}$ of RT StrataScript enzyme was then added. The samples were incubated at $42^{\circ} \mathrm{C}$ for $1 \mathrm{~h}$. Real-time PCR assays were carried out using Platinum Sybr Green qPCR Supermix-UDG (Invitrogen) in an iCycler iQ apparatus (BioRad Laboratories, Hercules, CA, U.S.A.). The reactions were conducted in a total volume of $25 \mu \mathrm{l}$, containing $12.5 \mu \mathrm{l}$ of $2 \times$ Platinum PCR Supermix-UDG, $300 \mathrm{nM}$ each primer (Supplementary Table S6), and 20 ng of cDNA template. The PCR cycling program consisted of: $50^{\circ} \mathrm{C}$ for $3 \mathrm{~min}, 95^{\circ} \mathrm{C}$ for $3 \mathrm{~min}$, and 40 cycles each consisting of $95^{\circ} \mathrm{C}$ for $30 \mathrm{~s}$ and $60^{\circ} \mathrm{C}$ for $30 \mathrm{~s}$.

A melting curve $\left(55\right.$ to $95^{\circ} \mathrm{C}$ with a heating rate of $0.5^{\circ} \mathrm{C}$ per $10 \mathrm{~s}$ and a continuous fluorescence measurement) was recorded at the end of each run to assess amplification product specificity. All reactions were performed with three technical replicates and three biological replicates. PCR efficiency was determined from standard curves constructed of serial dilutions of tomato genomic DNA. The comparative threshold cycle method (Rasmussen 2001) was used to calculate the relative expression level using ubiquitin (accession number X58253) as housekeeping gene.

\section{Virus concentration.}

Virus concentration was measured by qRT-PCR (detailed above) with primers q-TSWV_492(+) (5'-TGTCTTGGCTAT ATATCAGGATGCA-3') and q-TSWV_570(-) (5'-TAAGGCT TCCCTGGTGTCATACTT-3'), amplifying a portion of the $\mathrm{N}$ gene of the TSWV genome. Relative quantity of virus was calculated using ubiquitin (accession number X58253) as reference gene.

\section{Hormone detection.}

Plant shoots and roots harvested at 14 dpi were immediately frozen in liquid nitrogen. Samples were transferred to 2-ml tubes and ground in a bead beater (Qiagen) with 3-mm tungsten beads at $25 \mathrm{~Hz} / \mathrm{s}$ for $3 \mathrm{~min}$. For each shoot sample, two aliquots of approximately $20 \mathrm{mg}$ of powdered tissue (approximately $220 \mathrm{mg}$ fresh weight) were weighed and extracted with $500 \mu \mathrm{l}$ of extraction buffer $(10 \%$ [vol/vol] methanol containing $1 \%$ [vol/vol] acetic acid). One aliquot was added with internal standards (10 ng of ABA, $15 \mathrm{ng}$ of JA, and $200 \mathrm{ng}$ of SA) and used for recovery calculation. For each treatment, an extraction control without plant material was performed. Samples were extracted in an orbital shaker at $4^{\circ} \mathrm{C}$ in the dark for $1 \mathrm{~h}$ and then centrifuged at $13,000 \times g$ for $10 \mathrm{~min}$ at $4^{\circ} \mathrm{C}$. Supernatant was carefully removed and the pellet reextracted twice with $300 \mu \mathrm{l}$ of extraction buffer as before. The supernatants were pooled and centrifuged again to pellet any particulate material. Root extraction was performed on an initial amount of approximately 30 to $40 \mathrm{mg}$; extraction buffer volumes were 1000,500 , and $500 \mu \mathrm{l}$ for first, second, and third extraction, respectively. Supernatant $(200 \mu \mathrm{l})$ was directly analyzed for SA concentration while the remnant was purified through a 1-ml Weak Anion Exchange \& Reverse-Phase column (Strata-XAW; Phenomenex, Torrance, CA, U.S.A.) previously activated with $1 \mathrm{ml}$ of methanol and equilibrated with $1 \mathrm{ml}$ of extraction buffer. Columns were washed with $1 \mathrm{ml}$ of $25 \mathrm{mM}$ sodium acetate and samples were eluted in $1 \mathrm{ml}$ of methanol with $2 \%$ ( vol/vol) formic acid. Samples were concentrated in speed-vac at one-third of their initial volume and were analyzed by liquid chromatography (LC) tandem mass spectrometry (MS/MS) (ACQUITY UPLC System; Waterstown, U.K.). The liquid chromatograph was equipped with a $2.1-\mathrm{mm}$ by $50-\mathrm{mm}$ by 1.7- $\mu \mathrm{m}$ ACQUITY UPLC BEH C18 column and was used with a binary solvent system comprising water (A) and acetonitrile containing $0.05 \%$ acetic acid (B). Separations were performed using a gradient of increasing solvent B content

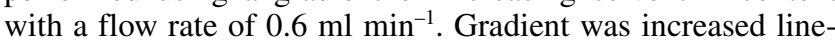
arly from 3 to $30 \% \mathrm{~B}$ over $1.5 \mathrm{~min}$ and then $95 \% \mathrm{~B}$ at $1.6 \mathrm{~min}$. After $0.5 \mathrm{~min}$ of exponential increase until $98 \% \mathrm{~B}$, the initial condition was restored $(3 \% \mathrm{~B})$ and allowed to equilibrate for 2 min. Retention times of the compounds were 1.07 (SA), 1.88 (ABA), and $1.97 \mathrm{~min}$ (JA). MS/MS conditions were as follows: capillary $(\mathrm{kV})=2.6$; source temperature $\left({ }^{\circ} \mathrm{C}\right)=120$; desolvation temperature $\left({ }^{\circ} \mathrm{C}\right)=400$; cone gas flow $\left(\right.$ liter $\left.\mathrm{h}^{-1}\right)=$ 0 ; desolvation gas flow (liter $\left.\mathrm{h}^{-1}\right)=800$; multiplier $(\mathrm{V})=650$; cone voltage $=35(\mathrm{ABA}), 32(\mathrm{JA})$, and $31(\mathrm{SA})$; collision energy $=12.0(\mathrm{ABA}), 14.0(\mathrm{JA})$, and $16.0(\mathrm{SA})$; and MS/MS transition $(\mathrm{m} / \mathrm{z})=263.2 / 153(\mathrm{ABA}), 209.1 / 58.9(\mathrm{JA})$, and 136.9/92.8 (SA).

Microarray data are available in the ArrayExpress database under accession number E-MTAB-620.

\section{ACKNOWLEDGMENTS}

This work was funded, in part, by the projects "GenoPom" (MIUR, Italy) and B74 (Ricerca Scientifica Applicata 2004, Regione Piemonte, Italy). We thank P. Davey for his advice on running the LC/MS/MS and M. Novero and M. Vecchiati for technical assistance with the plants.

\section{LITERATURE CITED}

Alvarez, M. E. 2000. Salicylic acid in the machinery of hypersensitive cell death and disease resistance. Plant Mol. Biol. 44:429-442.

Aroca, R., Vernieri, P., and Ruiz-Lozano, J. M. 2008. Mycorrhizal and non-mycorrhizal Lactuca sativa plants exhibit contrasting responses to exogenous ABA during drought stress and recovery. J. Exp. Bot. 59:2029-2041.

Asselbergh, B., Achuo, A. E., Höfte, M., and Van Gijsegem, F. 2008a. Abscisic acid deficiency leads to rapid activation of tomato defence responses upon infection with Erwinia chrysanthemi. Mol. Plant Pathol. 9:11-24.

Asselbergh, B., De Vleesschauwer, D., and Höfte, M. 2008b. Global switches and fine-tuning-ABA modulates plant pathogen defense. Mol Plant-Microbe Interact. 21:709-719.

Bari, R., and Jones, J .D. G. 2008. Role of plant hormones in plant defence responses. Plant Mol. Biol. 69:473-488.

Beckers, G. J. M., and Conrath, U. 2007. Priming for stress resistance: From the lab to the field. Curr. Opin. Plant Biol. 10:425-431.

Beffa, R. S., Hofer, R. M., Thomas, M., and Meins, F. 1996. Decreased susceptibility to viral disease of [beta]-1,3-glucanase-deficient plants generated by antisense transformation. Plant Cell 8:1001-1011.

Benhamou, N., Fortin, A., Hamel, C., St-Arnaud, M., and Shatilla, A. 1994. Resistance responses of mycorrhizal Ri T-DNA-transformed carrot roots to infection by Fusarium oxysporum f. sp. chrysanthemi. Phytopathology 84:958-968.

Blee, K. A., and Anderson, A. J. 2002. Transcripts for genes encoding soluble acid invertase and sucrose synthase accumulate in root tip and cortical cells containing mycorrhizal arbuscules. Plant Mol. Biol. 50:197-211.

Blilou, I., Ocampo, J. A., and García-Garrido, J. M. 2000. Induction of Ltp (lipid transfer protein) and Pal (phenylalanine ammonia-lyase) gene expression in rice roots colonized by the arbuscular mycorrhizal fungus Glomus mosseae. J. Exp. Bot. 51:1969-1977.

Bluthgen, N., Kiełbasa, S. M., and Herzel, H. 2005. Inferring combinatorial regulation of transcription in silico. Nucleic Acids Res. 33:272-279.

Bonfante, P., and Anca, I. 2009. Plants, mycorrhizal fungi, and bacteria: A network of interactions. Annu. Rev. Microbiol. 63:363-383.

Bonfante, P., and Genre, A. 2010. Mechanisms underlying beneficial plantfungus interactions in mycorrhizal symbiosis. Nat. Comms. 1:1-11. 
Borer, E. T., Seabloom, E. W., Mitchell, C. E., and Power, A. G. 2010. Local context drives infection of grasses by vector-borne generalist viruses. Ecol. Lett. 13:810-818.

Bucher, G. L., Tarina, C., Heinlein, M., Di Serio, F., Meins, F., Jr., and Iglesias, V. A. 2001. Local expression of enzymatically active class I beta-1, 3-glucanase enhances symptoms of TMV infection in tobacco. Plant J. 28:361-369

Catoni, M., Miozzi, L., Fiorilli, V., Lanfranco, L., and Accotto, G. P. 2009. Comparative analysis of expression profiles in shoots and roots of tomato systemically infected by Tomato spotted wilt virus reveals organ-specific transcriptional responses. Mol. Plant-Microbe Interact. 22:1504-1513.

Chaturvedi, R., and Shah, J. 2007. Salicylic acid in plant disease resistance. Pages 335-370 in: Salicylic Acid: A Plant Hormone. S. Hayat and A. Ahmad, eds. Springer, Dordrecht, The Netherlands.

Clark, M. F., and Adams, A. N. 1977. Characteristics of the microplate method of enzyme-linked immunosorbent assay for the detection of plant viruses. J. Gen. Virol. 34:475-483.

Conesa, A., Götz, S., García-Gómez, J. M., Terol, J., Talón, M., and Robles, M. 2005. Blast2GO: A universal tool for annotation, visualization and analysis in functional genomics research. Bioinformatics 21:3674-3676.

Conrath, U., Beckers, G. J. M., Flors, V., García-Agustín, P., Jakab, G., Mauch, F., Newman, M., Pieterse, C. M. J., Poinssot, B., and Pozo, M. J. 2006. Priming: Getting ready for battle. Mol. Plant-Microbe Interact. 19:1062-1071.

Cordier, C., Pozo, M. J., Barea, J. M., Gianinazzi, S., and GianinazziPearson, V. 1998. Cell defense responses associated with localized and systemic resistance to Phytophthora parasitica induced in tomato by an arbuscular mycorrhizal fungus. Mol. Plant-Microbe Interact. 11:10171028

Daft, M. J., and Okusanya, B. O. 1973. Effect of endogone mycorrhiza on plant growth v. influence of infection on the multiplication of viruses in tomato, petunia and strawberry. New Phytol. 72:975-983.

Dardick, C. 2007. Comparative expression profiling of Nicotiana benthamiana leaves systemically infected with three fruit tree viruses. Mol. Plant-Microbe Interact. 20:1004-1017.

Dehne, H. 1982. Interaction between vesicular arbuscular mycorrhizal fungi and plant pathogens. Phytopathology 72:1115-1119.

de la Peña, E., Echeverría, S. R., van der Putten, W. H., Freitas, H., and Moens, M. 2006. Mechanism of control of root-feeding nematodes by mycorrhizal fungi in the dune grass Ammophila arenaria. New Phytol. 169:829-840.

Dong, X. 1998. SA, JA, ethylene, and disease resistance in plants. Curr Opin. Plant Biol. 1:316-323.

Dong, X. 2004. NPR1, all things considered. Curr. Opin. Plant Biol. 7:547-552.

Dugassa, G. D., Alten, H., and Schönbeck, F. 1996. Effects of arbuscular mycorrhiza AM. on health of Linum usitatissimum L. infected by fungal pathogens. Plant Soil 185:173-182.

Dumas-Gaudot, E., Gollotte, A., Cordier, C., Gianinazzi, S., and GianinazziPearson, V. 2000. Modulation of host defence systems. Pages 173-200 in: Arbuscular Mycorrhizas: Physiology and Function. Y. Kapulnik and D. Douds, eds. Kluwer Academic Publishers, Dordrecht, The Netherlands.

Erb, M., Lenk, C., Degenhardt, J., and Turlings, T. C. 2009. The underestimated role of roots in defense against leaf attackers. Trends Plant Sci. 14:653-659.

Fiorilli, V., Catoni, M., Miozzi, L., Novero, M., Accotto G. P., and Lanfranco, L. 2009. Global and cell-type gene expression profiles in tomato plants colonized by an arbuscular mycorrhizal fungus. New Phytol. 184:975-987.

Fiorilli, V., Catoni, M., Francia, D., Cardinale, F., and Lanfranco, L. 2011. The arbuscular mycorrhizal symbiosis reduces disease severity in tomato plants infected by Botrytis cinerea. J. Plant Pathol. 93:237242.

Flors, V., Ton, J., van Doorn, R., Jakab, G., García-Agustín, P., and Mauch-Mani, B. 2008. Interplay between JA, SA and ABA signalling during basal and induced resistance against Pseudomonas syringae and Alternaria brassicicola. Plant J. 54:81-92.

Fraser, R. S. S. 1982. Are 'pathogenesis-related' proteins involved in acquired systemic resistance of tobacco plants to tobacco mosaic virus? J. Gen. Virol. 58:305-313.

Fritz, M., Jakobsen, I., Lyngkjær, M. F., Thordal-Christensen, H., and Pons-Kühnemann, J. 2006. Arbuscular mycorrhiza reduces susceptibility of tomato to Alternaria solani. Mycorrhiza 16:413-419.

Gange, A. 2007. Insect-mycorrhizal interactions: Patterns, processes, and consequences. Pages 124-144 in: Indirect Interaction Webs: Nontrophic Linkages Through Induced Plant Traits. T. Ohgushi, T. Craig, and P. Price, eds. Cambridge University Press, Cambridge.
Gange, A. C., and West, H. M. 1994. Interactions between arbuscular mycorrhizal fungi and foliar-feeding insects in Plantago lanceolata L. New. Phytol. 128:79-87.

Gernns, H., Alten, H., and Poehling, H. 2001. Arbuscular mycorrhiza increased the activity of a biotrophic leaf pathogen-is a compensation possible? Mycorrhiza 11:237-243.

Guether, M., Balestrini, R., Hannah, M., He, J., Udvardi, M. K., and Bonfante, P. 2009. Genome-wide reprogramming of regulatory networks, transport, cell wall and membrane biogenesis during arbuscular mycorrhizal symbiosis in Lotus japonicus. New Phytol. 182:200-212.

Gutjahr, C., and Paszkowski, U. 2009. Weights in the balance: Jasmonic acid and salicylic acid signaling in root-biotroph interactions. Mol. Plant-Microbe Interact. 22:763-772.

Harrison, M. J., and Dixon, R. A. 1993. Isoflavonoid accumulation and expression of defense gene transcripts during the establishment of vesicular-arbuscular mycorrhizal associations in roots of Medicago truncatula. Mol. Plant-Microbe Interact. 6:643-654.

Hause, B., Maier, W., Miersch, O., Kramell, R., and Strack, D. 2002. Induction of jasmonate biosynthesis in arbuscular mycorrhizal barley roots. Plant Physiol. 130:1213-1220.

Hause, B., Mrosk, C., Isayenkov, S., and Strack, D. 2007. Jasmonates in arbuscular mycorrhizal interactions. Phytochemistry 68:101-110.

Herbers, K., Takahata, Y., Melzer, M., Mock, H. P., Hajirezaei, M., and Sonnewald, U. 2000. Regulation of carbohydrate partitioning during the interaction of Potato virus $Y$ with tobacco. Mol. Plant Pathol. 1:51-59.

Herrera-Medina, M. J., Steinkellner, S., Vierheilig, H., Ocampo Bote, J. A., and García Garrido, J. M. 2007. Abscisic acid determines arbuscule development and functionality in the tomato arbuscular mycorrhiza. New Phytol. 175:554-564.

Herrera-Medina, M. J., Tamayo, M. I., Vierheilig, H., Ocampo, J. A., and García-Garrido, J. M. 2008. The jasmonic acid signalling pathway restricts the development of the arbuscular mycorrhizal association in tomato. J. Plant Growth Regul. 27:221-230.

Hewitt, E. J. 1966. Sand and Water Culture Methods Used in the Study of Plant Nutrition, 2nd ed. Commonwealth Agricultural Bureaux, Farnham Royal, England.

Hildebrandt, U., Regvar, M., and Bothe, H. 2007. Arbuscular mycorrhiza and heavy metal tolerance. Phytochemistry 68:139-146.

Isayenkov, S., Mrosk, C., Stenzel, I., Strack, D., and Hause, B. 2005. Suppression of allene oxide cyclase in hairy roots of Medicago truncatula reduces jasmonate levels and the degree of mycorrhization with Glomus intraradices. Plant Physiol. 139:1401-1410.

Javot, H., Pumplin, N., and Harrison, M. J. 2007. Phosphate in the arbuscular mycorrhizal symbiosis: Transport properties and regulatory roles. Plant Cell Environ. 30:310-322.

Kovač, M., Müller, A., Milovanovič Jarh, D., Milavec, M., Düchting, P., and Ravnikar, M. 2009. Multiple hormone analysis indicates involvement of jasmonate signalling in the early defence of potato to potato virus YNTN. Biol. Plant 53:195-199.

Li, H. Y., Yang, G. D., Shu, H. R., Yang, Y. T., Ye, B. X., Nishida, I., and Zheng, C. C. 2006. Colonization by the arbuscular mycorrhizal fungus Glomus versiforme induces a defense response against the root-knot nematode Meloidogyne incognita in the grapevine (Vitis amurensis Rupr.), which includes transcriptional activation of the class III chitinase gene VCH3. Plant Cell Physiol. 47:154-163.

Lindermann, R. 1994. Role of VAM fungi in biocontrol. Pages 1-25 in: Mycorrhizae and Plant Health. F. Pfleger and R. Lindermann, eds. The American Phytopathological Society Press, St. Paul, MN, U.S.A.

Lingua, G., D’Agostino, G., Massa, N., Antosiano, M., and Berta, G. 2002. Mycorrhiza-induced differential response to a yellows disease in tomato. Mycorrhiza 12:191-198.

Liu, J., Maldonado-Mendoza, I., Lopez-Meyer, M., Cheung, F., Town, C D., and Harrison, M. J. 2007. Arbuscular mycorrhizal symbiosis is accompanied by local and systemic alterations in gene expression and an increase in disease resistance in the shoots. Plant J. 50:529-544.

López-Ráez, J.A., Verhage, A., Fernández, I., García, J.M., Azcón-Aguilar, C., Flors, V., and Pozo, M.J. 2010. Hormonal and transcriptional profiles highlight common and differential host responses to arbuscular mycorrhizal fungi and the regulation of the oxylipin pathway. J. Exp. Bot. 61:2589-2601.

Maksimov, I. V. 2009. Abscisic acid in the plants-pathogen interaction. Russ. J. Plant Physiol. 56:742-752.

Martín-Rodríguez, J., León-Morcillo, R., Vierheilig, H., Ocampo, J. A. Ludwig-Müller, J., and García-Garrido, J. M. 2011. Ethylene-dependent/ethylene-independent ABA regulation of tomato plants colonized by arbuscular mycorrhiza fungi. New Phytol. 190:193-205.

Mauch-Mani, B., and Mauch, F. 2005. The role of abscisic acid in plantpathogen interactions. Curr. Opin. Plant Biol. 8:409-414.

Maule, A., Leh, V., and Lederer, C. 2002. The dialogue between viruses and hosts in compatible interactions. Curr. Opin. Plant Biol. 5:279-284. 
Parniske, M. 2008. Arbuscular mycorrhiza: The mother of plant root endosymbioses. Nat. Rev. Microbiol. 6:763-775.

Pennazio, S. 2010. Recovery. An enigmatic and neglected form of plant resistance to viruses. Riv. Biol. 103:51-70.

Penninckx, I. A., Thomma, B. P., Buchala, A., Métraux, J. P., and Broekaert, W. F. 1998. Concomitant activation of jasmonate and ethylene response pathways is required for induction of a plant defensin gene in Arabidopsis. Plant Cell. 10:2103-2113.

Pozo, M. J., and Azcón-Aguilar, C. 2007. Unraveling mycorrhiza-induced resistance. Curr. Opin. Plant Biol. 10:393-398.

Pozo, M. J., Cordier, C., Dumas-Gaudot, E., Gianinazzi, S., Barea, J. M., and Azcón-Aguilar, C. 2002. Localized versus systemic effect of arbuscular mycorrhizal fungi on defence responses to Phytophthora infection in tomato plants. J. Exp. Bot. 53:525-534.

Pozo, M. J., Jung, S. C., Lòpez-Ràez, J., and Azcón-Aguilar, C. 2010. Impact of arbuscular mycorrhizal symbiosis on plant response to biotic stress: The role of plant defence mechanisms. Pages 193-207 in: Arbuscular Mycorrhizas: Physiology and Function, 2nd ed. H Koltai and Y Kapulnik, eds. Springer-Verlag, Heidelberg, Germany.

Rasmussen, R. 2001. Quantification on the LightCycler instrument. Pages 21-34 in: Rapid Cycle Real-Time PCR: Methods and Applications. S. Meuer, C. Wittwer, and K. Nakagawara, eds. Springer-Verlag, Heidelberg, Germany.

Senthil, G., Liu, H., Puram, V. G., Clark, A., Stromberg, A., and Goodin, M. M. 2005. Specific and common changes in Nicotiana benthamiana gene expression in response to infection by enveloped viruses. J. Gen. Virol. 86:2615-2625.

Shalitin, D., and Wolf, S. 2000. Cucumber mosaic virus infection affects sugar transport in melon plants. Plant Physiol. 123:597-604.

Shaul, O., Galili, S., Volpin, H., Ginzberg, I., Elad, Y., Chet, I., and Kapulnik, Y. 1999. Mycorrhiza-induced changes in disease severity and PR protein expression in tobacco leaves. Mol. Plant-Microbe Interact. 12:1000-1007.

Singh, D. P., Moore, C. A., Gilliland, A., and Carr, J. P. 2004. Activation of multiple antiviral defence mechanisms by salicylic acid. Mol. Plant Pathol. 5:57-63.

Smyth, G. K., Michaud, J., and Scott, H. S. 2005. Use of within-array replicate spots for assessing differential expression in microarray experiments. Bioinformatics 21:2067-2075

Strack, D., and Fester, T. 2006. Isoprenoid metabolism and plastid reorganization in arbuscular mycorrhizal roots. New Phytol. 172:22-34.

Tecsi. L. I., Smith, A. M., Maule, A. J., and Leegood, R. C. 1996. A spatial analysis of physiological changes associated with infection of cotyledons of marrow plants with cucumber mosaic virus. Plant Physiol. 111:975-985.

Ton, J., and Mauch-Mani, B. 2004. Beta-amino-butyric acid-induced resis- tance against necrotrophic pathogens is based on ABA-dependent priming for callose. Plant J. 38:119-130.

Trouvelot, A., Kough, J. L., and Gianinazzi-Pearson, V. 1986. Mesure du taux de mycorhization VA d'un système radiculaire. Recherche de méthodes d'estimation ayant une signification fonctionnelle. Pages 217-221 in: Physiological and Genetical Aspects of Mycorrhizae. V. Gianinazzi-Pearson and S. Gianinazzi, eds. INRA, Paris.

Vaira, A. M., Semeria, L., Crespi, S., Lisa, V., Allavena, A., and Accotto, G. P. 1995. Resistance to tospoviruses in Nicotiana benthamiana transformed with the $N$ gene of tomato spotted wilt virus: Correlation between transgene expression and protection in primary transformants. Mol. Plant-Microbe Interact. 8:66-73.

Van der Heijden, M., and Sanders, I. 2002. Mycorrhizal Ecology. Springer, Berlin.

van Loon, L. C., and van Strien, E. A. 1999. The families of pathogenesisrelated proteins, their activities, and comparative analysis of PR-1 type proteins. Physiol. Mol. Plant Pathol. 55:85-97.

Volpin, H., Elkind, Y., Okon, Y., and Kapulnik, Y. 1994. A vesicular arbuscular mycorrhizal fungus Glomus intraradix induces a defense response in alfalfa roots. Plant Physiol. 104:683-689.

Volpin, H., Phillips, D. A., Okon, Y., and Kapulnik, Y. 1995. Suppression of an isoflavonoid phytoalexin defense response in mycorrhizal alfalfa roots. Plant Physiol. 108:1449-1454.

Wehnera, J., Antunesa, P. M., Powella, J. R., Mazukatowa, J., and Rillig, M. C. 2010. Plant pathogen protection by arbuscular mycorrhizas: A role for fungal diversity? Pedobiologia 53:197-201.

Whenham, R. J., Fraser, R. S. S., Brown, L. P., and Payne, J. A. 1986. Tobacco-mosaic-virus-induced increase in abscisic-acid concentration in tobacco leaves. Planta 168:592-598.

Whipps, J. M. 2004. Prospects and limitations for mycorrhizas in biocontrol of root pathogens. Can. J. Bot. 82:1198-1227.

Wilkinson, S., and Davies, W. J. 2010. Drought, ozone, ABA and ethylene: New insights from cell to plant to community. Plant Cell Environ. 33:510-525.

Yao, M. K., Désilets, H., Charles, M. T., Boulanger, R., and Tweddell, R. J. 2003. Effect of mycorrhization on the accumulation of rishitin and solavetivone in potato plantlets challenged with Rhizoctonia solani. Mycorrhiza 13:333-336.

Zavaliev, R., Ueki, S., Epel, B.L., and Citovsky, V. 2010. Biology of callose ( $\beta$-1,3-glucan) turnover at plasmodesmata. Protoplasma 248:117130.

\section{AUTHOR-RECOMMENDED INTERNET RESOURCE}

Sol Genomics unigene database: www.sgn.cornell.edu 